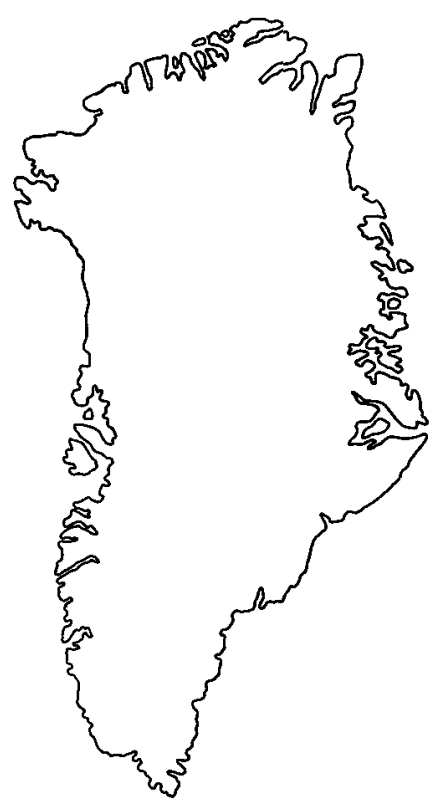

\title{
A review of Salterella (Phylum Agmata) from the Lower Cambrian in Greenland and Mexico
}

\author{
John S. Peel and Ellis L. Yochelson
}

\begin{abstract}
Records of Salterella from the Lower Cambrian in Greenland are reviewed and all specimens are referred to $S$. maccullochi (Murchison, 1859). Examples are illustrated for the first time from the Brønlund Fjord Group of Peary Land, central North Greenland and from the Hyolithus Creek Formation at Kap Weber and at C. H. Ostenfeld Nunatak, northern East Greenland.

S. mexicana Lochman in Cooper et al., 1952, from Sonora, Mexico, is illustrated in thin sections and is placed into synonymy with $S$. maccullochi.
\end{abstract}

J. S. P., Grønlands Geologiske Undersøgelse, Øster Voldgade 10, DK-1350 København K, Danmark.

E. L. Y., U. S. Geological Survey, Washington, D. C. 20560 , U.S.A.

This brief review of the distribution and nomenclature of the genus Salterella Billings, 1861 in Greenland was prompted by the recent re-description by Yochelson (in press) of Salterella maccullochi (Murchison, 1859) from the Northwest Highlands of Scotland. $S$. maccullochi is the earliest described species currently assigned to Salterella and it is considered by Yochelson to be a senior subjective synonym of $S$. rugosa Billings, 1861, the type and best known species of the genus. The recognition of this synonymy necessitates re-assignment of Greenland specimens from $S$. rugosa to $S$. maccullochi.

Salterella was first described from North-West Greenland more than fifty years ago (Poulsen, 1927; 1958; see Yochelson \& Peel, 1980) and has been subsequently described from northern East Greenland (Poulsen, 1932; Griffin \& Yochelson, 1975). Specimens are illustrated here for the first time from three additional localities in North and East Greenland; all are of Early Cambrian age.

The Greenland localities provide the northernmost record of Salterella on the present-day configuration of land and sea. During examination of collections from these localities, comparison has been made with the most southerly described specimens of Salterella, namely $S$. mexicana Lochman in Cooper et al., 1952, from Sonora, Mexico. It is our conclusion that $S$. mexicana is also a junior subjective synonym of $S$. maccullochi. The two records are of interest in view of their considerable geographic separation - more than 50 degrees of latitude or a distance in excess of $7000 \mathrm{~km}$. Both outcrops probably occupied a broad 


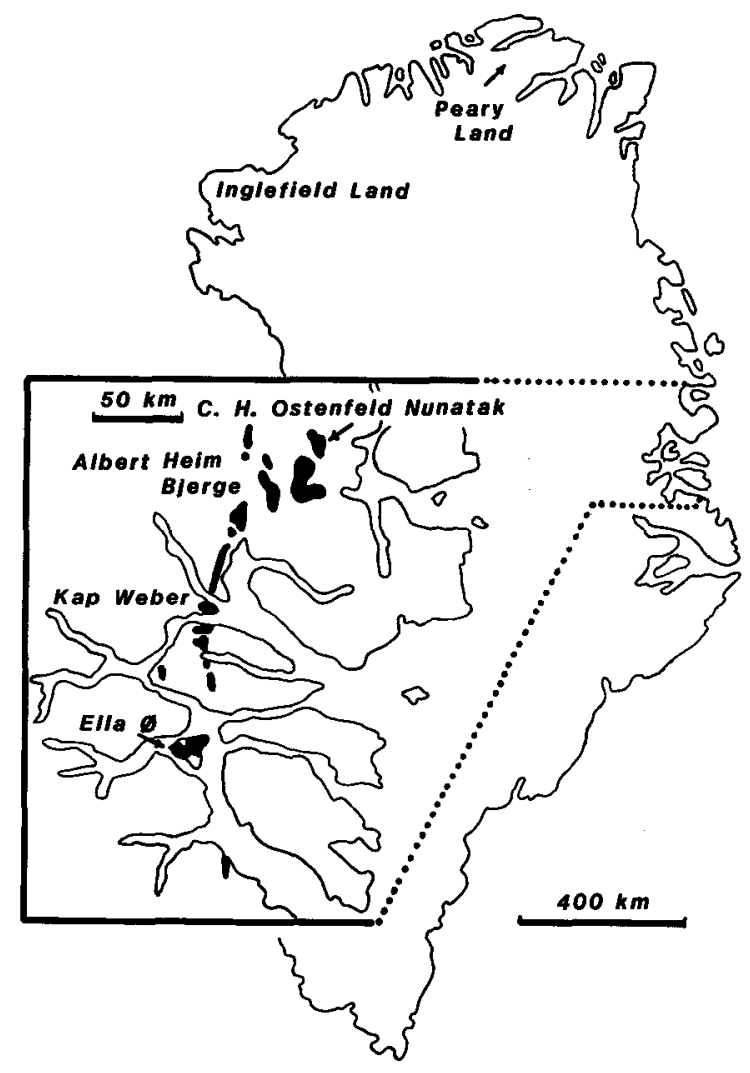

Fig. 1. Salterella localities in Greenland. Cambro-Ordovician outcrops in East Greenland are coloured black.

equatorial belt in Cambrian time, but the unchanged position of Greenland relative to mainland North America from the Cambrian to the present day (Christie et al., 1981; Dawes \& Kerr, 1982) maintains the separation.

\section{Records of Salterella from Greenland}

Salterella is now known from North-West Greenland, central North Greenland and northern East Greenland. Poulsen $(1927,1958)$ described Salterella expansa and an indeterminate species of Salterella from the Wulff River Formation of late Early Cambrian age in Inglefield Land (figs 1, 2). Yochelson \& Peel (1980) examined Poulsen's type specimens as well as new collections and considered $S$. expansa to be a junior subjective synonym of $S$. rugosa Billings, 1861, the type species of Salterella. Associated trilobites described by Poulsen $(1927,1958)$ indicate the Bonnia-Olenellus Zone of the Early Cambrian. S. rugosa was also identified by Poulsen (1932) from the Ella Island Formation of Ella $\emptyset$, northern East Greenland (figs 1,2) and the specimens were subsequently examined by Griffin \& Yochelson (1975). The associated fauna also includes olenellids and Bonnia (Cowie \& Adams, 1957). 


\begin{tabular}{|c|c|c|c|}
\hline INGLEFIELD LAND & \multicolumn{2}{|c|}{ PEARY LAND } & EAST GREENLAND \\
\hline $\begin{array}{l}\text { Cape Kent } \\
\text { Formation }\end{array}$ & \multirow{4}{*}{ 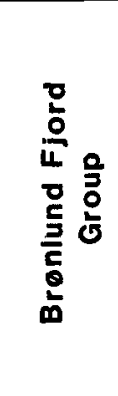 } & \multirow{2}{*}{$\begin{array}{l}\text { Formation } \\
6 \text { th }\end{array}$} & \multirow{2}{*}{$\begin{array}{l}\text { Hyolithus Creek } \\
\text { Formation }\end{array}$} \\
\hline $\begin{array}{l}\text { Wulff River } \\
\text { Formation }\end{array}$ & & & \\
\hline $\begin{array}{c}\text { Cape Ingersoll } \\
\text { Formation }\end{array}$ & & \multirow{2}{*}{$\begin{array}{c}\text { Formation } \\
1\end{array}$} & \multirow{2}{*}{$\begin{array}{l}\text { Ella Island } \\
\text { Formation }\end{array}$} \\
\hline $\begin{array}{l}\text { Cape Leiper } \\
\text { Formation }\end{array}$ & & & \\
\hline \multirow[t]{3}{*}{$\begin{array}{l}\text { Dallas Bugt } \\
\text { Formation }\end{array}$} & \multicolumn{2}{|c|}{ Buen Formation } & \multirow[t]{2}{*}{ Bastion Formation } \\
\hline & \multicolumn{2}{|c|}{ Portfjeld Formation } & \\
\hline & & & Kløftelv Formation \\
\hline
\end{tabular}

Fig. 2. Stratigraphic distribution of Salterella maccullochi in the Lower Cambrian of Greenland. The section in Peary Land is from the area around Jørgen Brønlund Fjord, in central southern Peary Land; four additional formations are recognised within the Brønlund Fjord Group in more westerly outcrops in Peary Land (Ineson \& Peel, 1980). No precise correlation is implied between the three sections. Occurrences of $S$. maccullochi are starred.

Troelsen (1956) recorded, but did not describe, Salterella from the basal Brønlund Fjord Dolomite of central southern Peary Land, central North Greenland (fig. 1). The strata from which the samples were collected are now referred to member A of formation 1 of the Brønlund Fjord Group (Ineson \& Peel, 1980). The identification was confirmed by Peel et al. (1974) on the basis of a few specimens in Troelsen's collections. The associated fauna is probably indicative of the Bonnia-Olenellus Zone (Palmer \& Peel, 1979). In 1980, J. S. P. collected abundant specimens of Salterella from higher levels of the Brønlund Fjord Dolomite in strata now assigned to formation 6 of the Brønlund Fjord Group (Ineson \& Peel, 1980; fig. 2 herein). These specimens are described and illustrated below (fig. 5). The Salterella-yielding beds pass laterally into dolomites rich in archaeocyathaceans and overlie dark, silty dolomites with rich invertebrate faunas of Bonnia-Olenellus Zone age.

Cowie \& Adams (1957) recorded Salterella from the Hyolithus Creek Formation at Kap Weber, Ella $\emptyset$ and Albert Heim Bjerge, northern East Greenland (figs 1, 2). This material is illustrated here for the first time (fig. 3). In the same publication, Cowie \& Adams (1957, footnote p. 45) noted specimens of Salterella collected by John Haller from C. H. Ostenfeld Nunatak, northern East Greenland, also from the Hyolithus Creek Formation (fig. 1). Haller's material is figured here for the first time (fig. 4). The sequence exposed on $\mathrm{C}$. $\mathbf{H}$. Ostenfeld Nunatak contains the most northerly exposures of Cambrian and Ordovician strata in the East Greenland region (Frykman, 1979). 

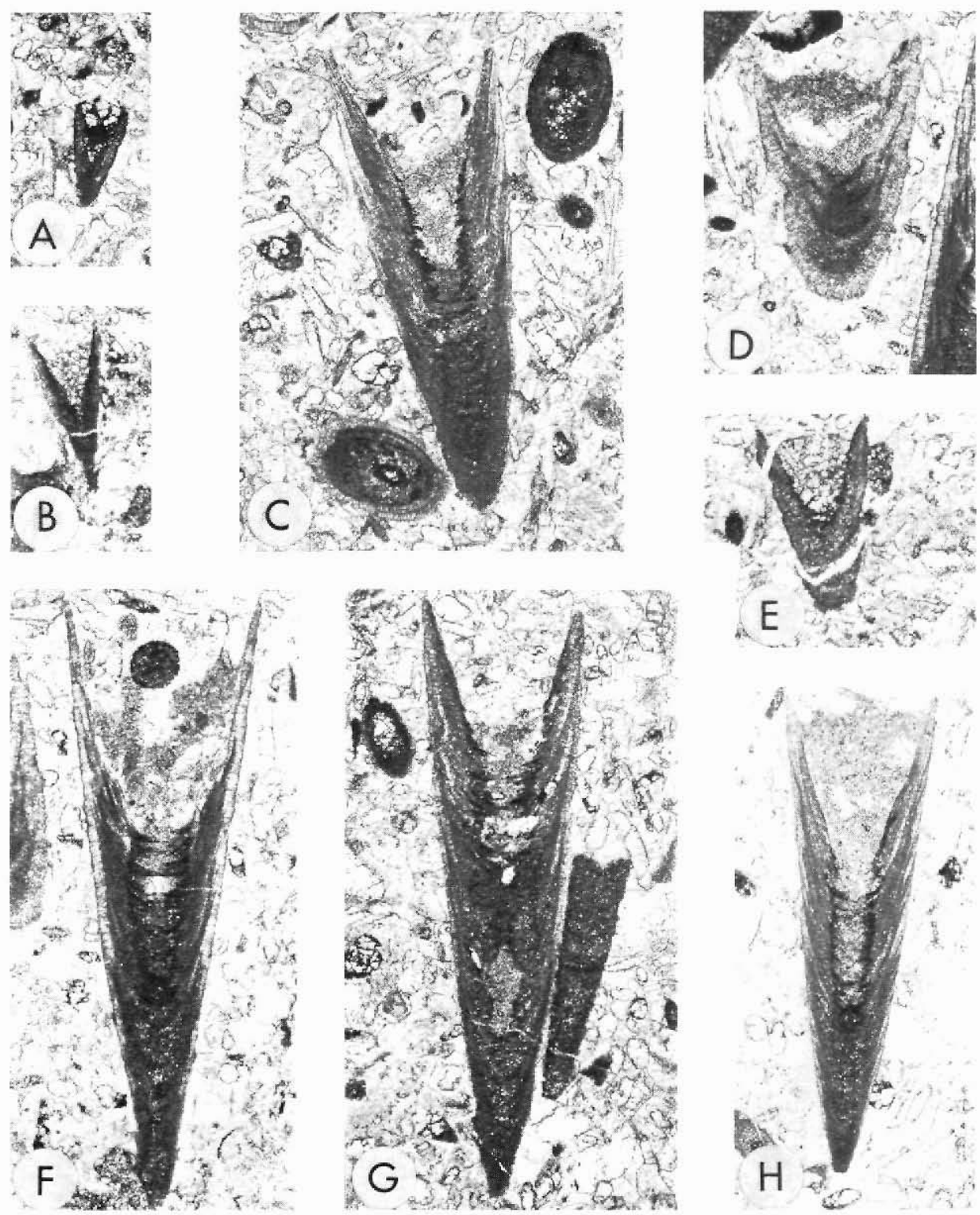

Fig. 3. Salterella maccullochi, Hyolithus Creek Formation, Kap Weber, northern East Greenland, $\times 10$. A-H, MGUH 15.913-15.920. Specimens collected by J. W. Cowie, locality 77. 

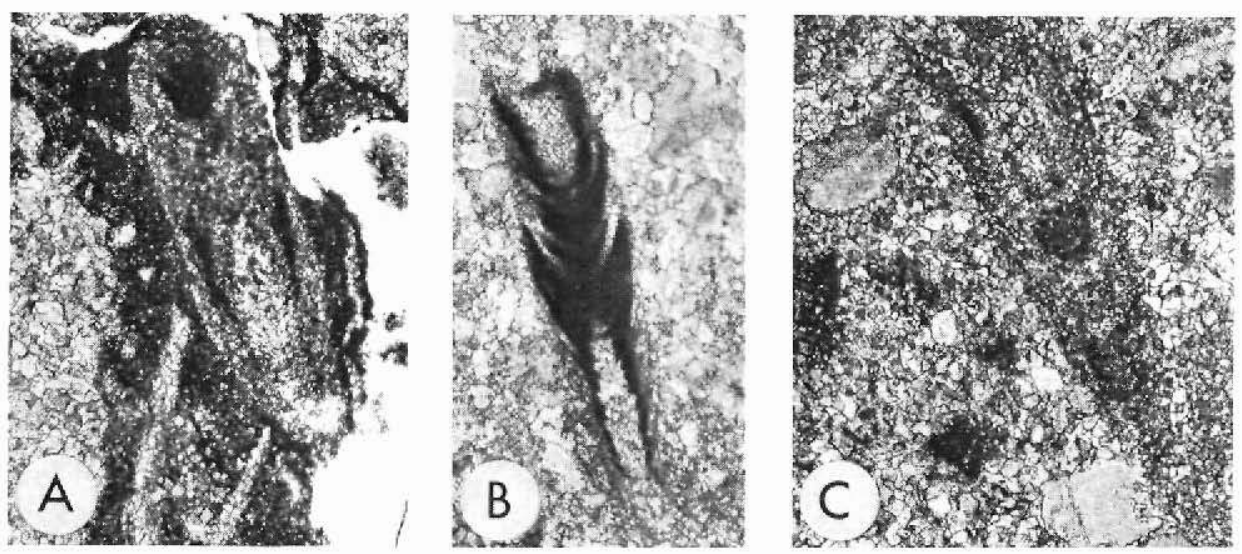

Fig. 4. Salterella maccullochi, Hyolithus Creek Formation, C. H. Ostenfeld Nunatak, northern East Greenland, $\times 10$. A-C, MGUH 15.895-15.897. Specimens collected by J. Haller, locality QERR.

Yochelson (in press) recently examined thin sections of specimens of Salterella maccullochi (Murchison, 1859) from the Northwest Highlands of Scotland and concluded that this, the first described species of Salterella, is a senior subjective synonym of $S$. rugosa Billings, 1861. The synonymy is currently extended to include all presently known specimens of Salterella from Greenland.

\section{Salterella from Mexico}

Lochman (in Cooper et al., 1952) gave the name Salterella mexicana to specimens from the Caborca region, Sonora, Mexico. These were illustrated in external view and as polished sections. One associated specimen was referred to $S$. cf. $S$. pulchella Billings, 1861 and some additional specimens were not determined to species. The material does not appear to have been redescribed subsequently, and we know of no additional records of Salterella from Mexico. Following examination of recently prepared thin sections, all the specimens are assigned to $S$. maccullochi. The single specimen of $S$. cf. $S$. pulchella is interpreted as a preservational variant, as tacitly implied by Lochman (in Cooper et al., 1952, p. 88).

\section{Systematic palaeontology}

Phylum Agmata Yochelson, 1977

Family Salterellidae Walcott, 1886

Genus Salterella Billings, 1861

Type species. Salterella rugosa Billings, 1861.

Salterella maccullochi (Murchison, 1859)

Figs 3-6

Serpulites MacCullochii Murchison, 1859, p. 222.

Salterella rugosa Billings, 1861, p. 954, fig. 362. 


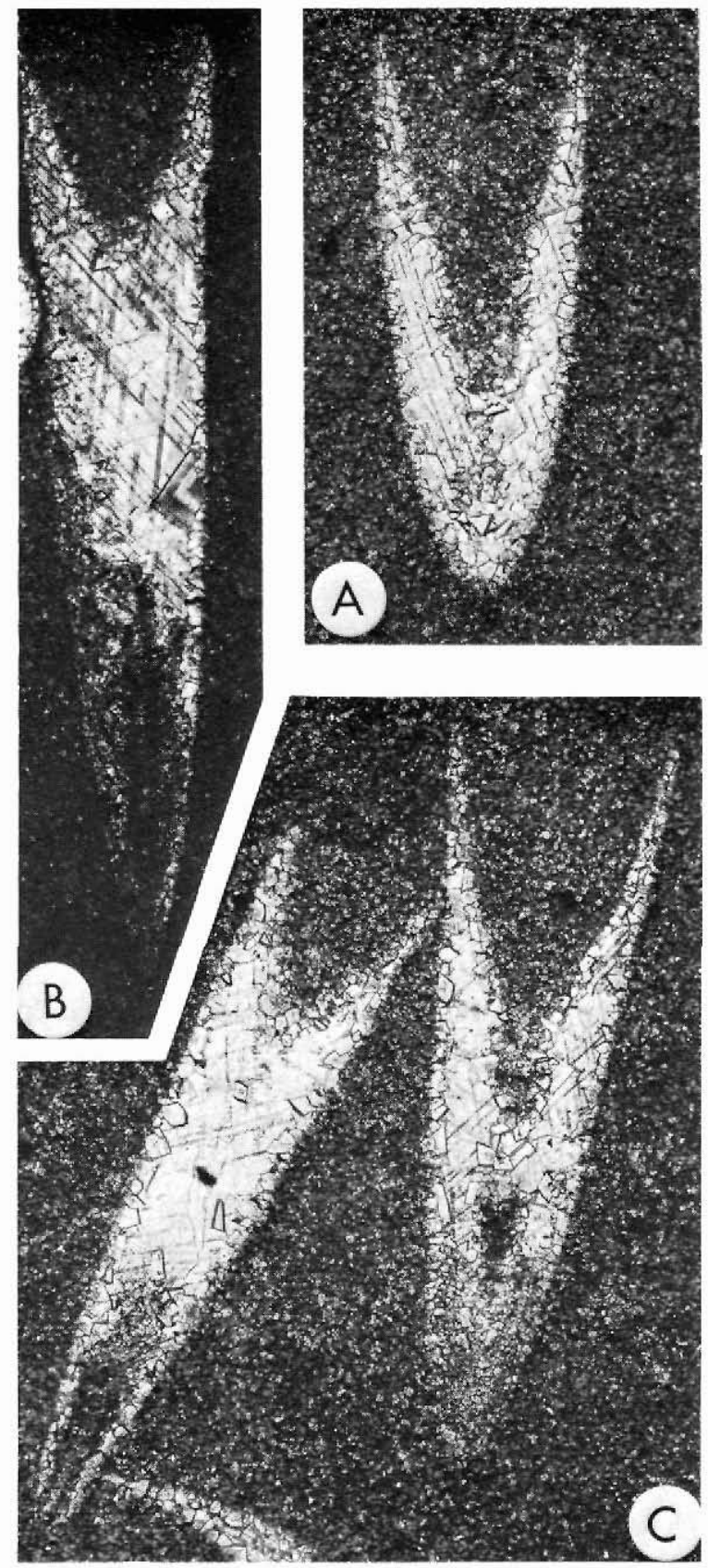

Fig. 5. Salterella maccullochi, Brønlund Fjord Group, formation 6, Paralleldal, central southern Peary Land, central North Greenland, $\times$ 10. A-C, MGUH 15.921-15.924 from GGU sample 274910. Specimens collected by J. S. Peel. 

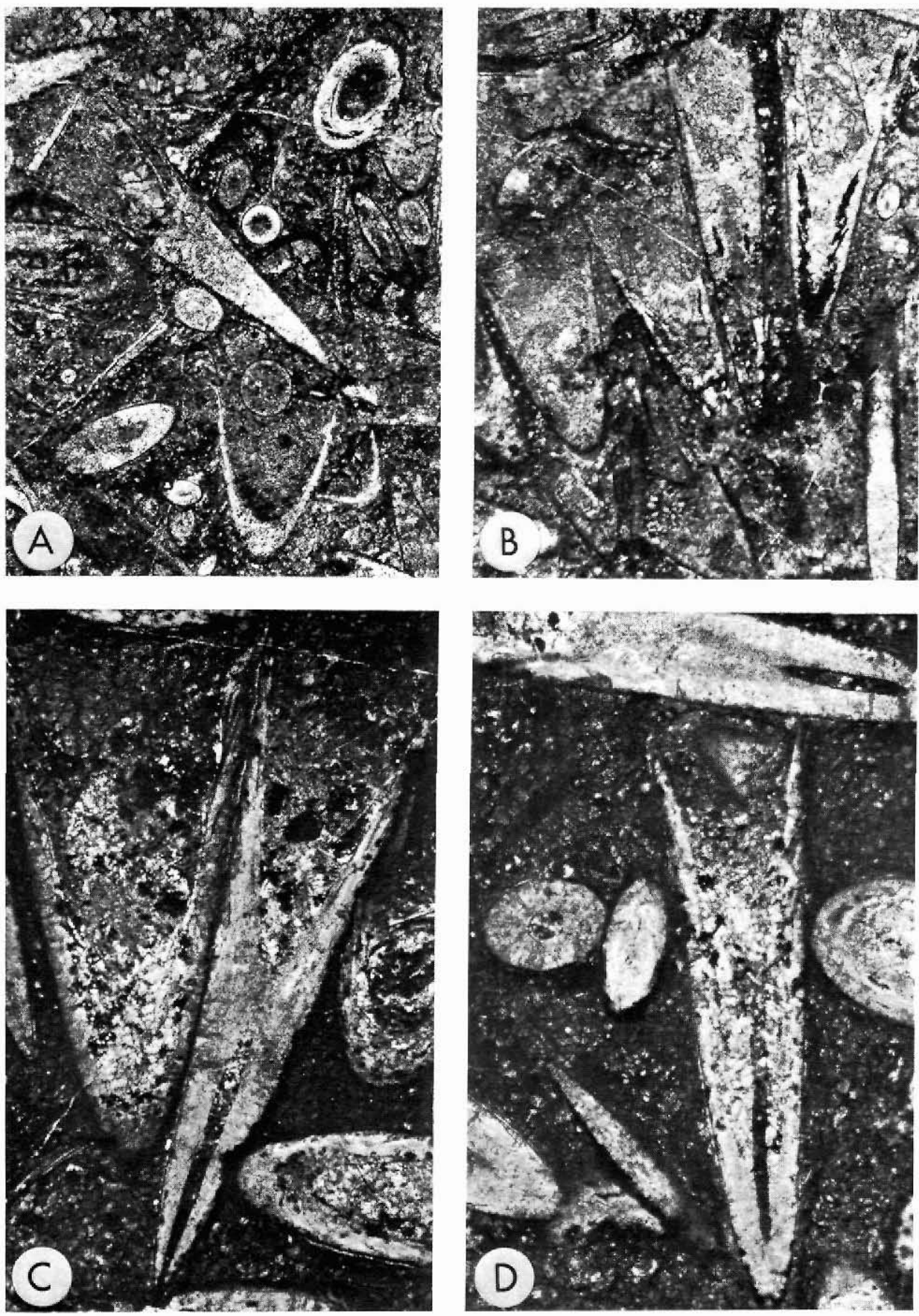

Fig. 6. Salterella maccullochi, Buelna Formation, Caborca, Sonora, Mexico. A, B, from USNM $115677 \mathrm{a}, \mathrm{b}$, a slab containing the holotype and one figured paratype of $S$. mexicana, $\times 10 . \mathrm{C}, \mathrm{D}$, from USNM $115674 \mathrm{a}-\mathrm{c}$, a slab containing figured paratypes of $S$. mexicana, $\times 15$. 
Salterella expansa Poulsen, 1927, p. 251, pl. XIV, figs 10-12.

Salterella sp. ind., Poulsen, 1927, p. 251-2, pl. XIV, fig. 13.

Salterella rugosa, Poulsen, 1932, p. 32-34, figs 5, 6; pl. 7, figs 11-15; pl. 8, figs 1, 2.

Salterella mexicana Lochman in Cooper et al., 1952, p. 85-87.

Salterella expansa, Poulsen, 1958, p. 10, pl. 1, figs 2, 3.

Salterella rugosa, Griffin \& Yochelson, 1975, p. 221-227, figs 1-9.

Salterella rugosa, Yochelson, 1977, p. 442-448, pl. 1, figs 1-4; pl. 2, figs 1, 2-7; pl. 3, figs 4,5 .

Salterella rugosa, Yochelson \& Peel, 1980, p. 33-35, figs 2-5.

Salterella maccullochi, Yochelson, in press.

Figured material. MGUH 15.913-15.920, from the Hyolithus Creek Formation, Kap Weber, northern East Greenland. MGUH 15.895-15.897, from the Hyolithus Creek Formation, C. H. Ostenfeld Nunatak, northern East Greenland. MGUH 15.921-15.924, from GGU sample 274910, Brønlund Fjord Group, formation 6 of Ineson \& Peel (1980), central North Greenland. USNM $115674 \mathrm{a}-\mathrm{c}, 115677 \mathrm{a}-\mathrm{b}$, from the Buelna Formation, Caborca, Sonora, Mexico.

Description. A full description of this species was given by Yochelson (in press). Descriptions and illustrations of $S$. rugosa were given by Yochelson (1977), Griffin \& Yochelson (1975), and Yochelson \& Peel (1980).

Discussion. The three collections of Salterella maccullochi illustrated here show contrasting states of preservation. Specimens from the Hyolithus Creek Formation at Kap Weber occur in limestone and are very well preserved (fig. 3). Details of the finer inner lamination and general structure of the conch are clearly visible. However, specimens showing breakage of the aperture and the apex are also present (fig. 3D, E). In marked contrast, the specimens of $S$. maccullochi from the Hyolithus Creek Formation at C. H. Ostenfeld Nunatak are poorly preserved in dolomite. Features of the inner lamination and the apertural cavity are discernible in the recrystallised carbonate, but the 'ghosts' visible in thin section are incomplete and often appear to lack the conch wall (fig. 4). In this respect, they resemble Volborthella Schmidt, 1888, long considered to be a separate genus but now known to be based on specimens of Salterella from which the outer wall has been removed by erosion or solution (Yochelson, 1977; 1981).

The specimens of $S$. maccullochi from North Greenland (fig. 5) are also preserved in dolomite. The matrix is an exceedingly tough, massive, pale buff grey dolomite which, in thin section, is seen to be weakly mottled. The conchs of $S$. maccullochi generally appear to be complete and outlines show well-preserved apices and apertural margins. However, the entire conch has recrystallised to spar and all details of internal structure have been lost (fig. 5).

It has now proved possible to examine thin sections of $S$. mexicana Lochman in Cooper $e t$ al., 1952 (fig. 6). The species has previously been illustrated from polished sections and external views but the thin sections have only recently become available. After study of the thin sections, it is our conclusion that $S$. mexicana is also a junior subjective synonym of $S$. maccullochi.

Acknowledgments. We are grateful to the Dept. of Paleobiology, U.S. Natural History Museum, for permission to prepare thin sections from the type collection of $S$. mexicana (USNM prefix). MGUH denotes specimens in the type collection of the Geological Museum, Copenhagen. 


\section{References}

Billings, E. 1861: On some new or little known species of Lower Silurian fossils from the Potsdam group (Primordial zone). In Hitchcock E. et al. Report on the geology of Vermont; descriptive, theoretical, economical, and scenographical, 942-955.

Christie, R. L., Dawes, P. R., Frisch, T., Higgins, A. K., Hurst, J. M., Kerr, J. Wm. \& Peel, J. S. 1981: Geological evidence against major displacement in the Nares Strait. Nature 291, 478-480.

Cooper, G. A., Arellano, A. R. V., Johnson, J. H., Okulitch, V. J., Stoyanow, A. \& Lochman, C. 1952: Cambrian stratigraphy and paleontology near Caborca, Northwestern Sonora, Mexico. Smithson. misc. Colls 119(1), $186 \mathrm{pp}$.

Cowie, J. W. \& Adams, P. J. 1957: The geology of the Cambro-Ordovician rocks of central East Greenland. Part I: Stratigraphy and structure. Meddr Grønland 153(1), 193 pp.

Dawes, P. R. \& Kerr, J. W. 1982: The case against major displacement along Nares Strait. In Dawes, P. R. \& Kerr, J. W. (edit.) Nares Strait and the drift of Greenland: a conflict in plate tectonics. Meddr Grønland, Geoscience 8, 369-386.

Frykman, P. 1979: Cambro-Ordovician rocks of C. H. Ostenfeld Nunatak, northern East Greenland. Rapp. Grønlands geol. Unders. 91, 125-132.

Griffin, W. L. \& Yochelson, E. L. 1975: Mineralogy of Early Cambrian Salterella rugosa from East Greenland. Bull. geol. Soc. Denmark 24, 221-227.

Ineson, J. R. \& Peel, J. S. 1980: Cambrian stratigraphy in Peary Land, eastern North Greenland. Rapp. Grønlands geol. Unders. 99, 33-42.

Murchison, R. I. 1859: Siluria, the history of the oldest fossiliferous rocks and their foundations; with a brief sketch of the distribution of gold over the earth. Third edition, $592 \mathrm{pp}$. London: John Murray.

Palmer, A. R. \& Peel, J. S. 1979: New Cambrian faunas from Peary Land, eastern North Greenland. Rapp. Grønlands geol. Unders. 91, 29-36.

Peel, J. S., Dawes, P. R. \& Troelsen, J. C. 1974: Notes on some Lower Palaeozoic to Tertiary faunas from eastern North Greenland. Rapp. Grønlands geol. Unders. 65, 18-23.

Poulsen, C. 1927: The Cambrian, Ozarkian and Canadian faunas of Northwest Greenland. Meddr Grønland 70(1), 2, 233-343.

Poulsen, C. 1932: The Lower Cambrian faunas of East Greenland. Meddr Grønland 87(6), 66 pp.

Poulsen, C. 1958: Contribution to the palaeontology of the Lower Cambrian Wulff River Formation. Meddr Grønland 162(2), $25 \mathrm{pp}$.

Troelsen, J. C. 1956: The Cambrian of North Greenland and Ellesmere Island. In El sistema Càmbrico su paleogeografía y el problema du base. 20 Congr. geol. int. Mexico. Symp. 3(1), 71-90.

Yochelson, E. L. 1977: Agmata, a proposed extinct phylum of early Cambrian age. J. Paleont. 51, 437-454.

Yochelson, E. L. 1981: A survey of Salterella (Phylum Agnata). In Taylor, M. E. (edit.) Short papers for the Second International Symposium on the Cambrian System 1981. Open-file report, U.S. geol. Survey 81-743, 244-248.

Yochelson, E. L. in press: Salterella (Early Cambrian; Agmata) from the northern Scottish Highlands. Palaeontology.

Yochelson, E. L. \& Peel, J. S. 1980: Early Cambrian Salterella from North-West Greenland. Rapp. Grønlands geol. Unders. 101, 29-36. 